\title{
Könyvszemle
}

SIPOS JÚLIA GONDOZÁSÁBAN

\section{BATTHYÁNY BOLDIZSÁR - MIÉRT FONTOS NEKÜNK?}

A 16. századi föúr, Batthyány Boldizsár több szempontból is különleges szereplő a történész számára, nem véletlen, hogy Bobory Dóra immár a harmadik könyvet szenteli neki. Először 2009-ben jelentette meg Angliában The Sword and the Crucible. Count Boldizsár Batthyány and Natural Philosophy in Sixteenth-Century Hungary címü monográfiáját, amit 2018-ban jelentősen átdolgozott és kiegészített a hazai olvasók számára, és a L'Harmattan Kiadó Mikrotörténelem sorozatában jelentetett meg (Batthyány Boldizsár titkos tudománya, Alkimia, botanika és könyvgyüjtés a tizenhatodik századi Magyarországon), most pedig a két feldolgozás forrásanyagát képező levelek szövegkiadását publikálta hazai kiadónál, de a nemzetközi szakközönségre is gondolva, angol nyelven.

De miért fontos nekünk Batthyány? Nyugat-magyarországi földbirtokosként Batthyány Boldizsár (1542-1590) meghatározó szerepet játszott a török elleni fizikai küzdelmekben és a Habsburg-uralkodóval szembeni politikai érdekérvényesítésben. Bár híresen kerülte a politikai megbízatásokat, helyzetéből adódóan nem kerülhette el, hogy a magyar nemesi érdekek szószólójává váljék az udvarban. De nem csak a nagypolitikában játszott fontos szerepet. Batthyány rendkívül olvasott ember volt, ugyanakkor kísérleteket végző, a fémekkel és az orvoslással kapcsolatos tapasztalatait levelezőpartnereivel megosztó szerző. Az idejét legszívesebben otthon töltő föúr a 16. századi alkímiatörténet egyik legjobban dokumentált alakja, így levelezése mind a hazai, mind a nemzetközi alkímiatörténészek (és tágabban: a tudománytörténészek) számára fontos forrásul szolgál.

A szakmában közhely ugyan, de a szélesebb olvasóközönség előtt nem feltétlenül ismert, hogy alkímián nem egyszerüen az aranycsinálás őrült és a múltban is sokat kritizált vágyálmát kell érteni. A kora újkori alkímia összetett elméleti és kísérleti tudomány volt, magába sürítette a fémek viselkedésével és keletkezésével, a bányászattal, a betegségekkel, a gyógyszerészettel, a világmindenség szerkezetével és az emberi kísérletező képesség határaival kapcsolatos nézeteket, elméleteket és praxisokat. E komplex vállalkozásnak a korszak számos értelmiségije, tudósa, nemese, de átlagpolgára is követőjéül szegődött, többek közt maga Isaac Newton. 
Az alkimista levelek persze számos egyéb információt tartalmaznak szerzőiktől, leggyakrabban a saját életükkel kapcsolatos apró-cseprő praktikus vagy érzelmi részeleteket, vallásos és politikai eseményekre reagáló megjegyzéseket, családi és egészségügyi észrevételeket, amelyek ezeket a forrásokat a mindennapi élet történészei számára is különleges jelentőséggel ruházzák fel. Nem véletlen a könyv alcíme: Egy kora újkori alkimista mindennapi élete.

A Batthyány-levéltár anyaga a huszadik században többször is jelentős pusztulást szenvedett, azonban még így is maradt egy kimagaslóan gazdag - igaz, meglehetősen aszimmetrikus - korpusz: mintegy 3300 Batthyány Boldizsárnak címzett levél szerte Európából, körülbelül 650 szerzőtől, amelyet hatvanöt saját szerzőségü levele egészít ki. Bár a forrásanyag gazdagsága nem volt ismeretlen a történészek előtt, korábban csupán pár tucat levél volt nyomtatásban olvasható. Most ebböl a korpuszból kapunk egy gazdag válogatást, amely az alkimista praxissal, a fémmegmunkálással és a bányászattal kapcsolatos tudományos tartalmú levelekre fókuszál, így összesen 298 levelet tartalmaz huszonhat levelezőpartnertől, amelyeket hét, Batthyány saját tollából származó levél egészít ki.

A levelek - Batthyány sokszínủ kapcsolatrendszerét tükrözve - soknyelvúek. Találunk köztük latin, német, francia és kisebb részt magyar nyelvü írásokat, kiadásuk a szerkesztőtől is speciális tudást igényel. De nemcsak a nyelvi nehézségek, a kézírás kibogarászása és a rövidítések értelmezése teszi értékes vállalkozássá a szövegkiadást, hanem az a szakmai tudás is, amely nélkül a fémmüvességgel kapcsolatos szövegek nem volnának érthetők, és amelynek részleteibe a szerző beavatja az olvasót. Ahelyett azonban, hogy elszórt lábjegyzetekben véletlenszerüen kommentálna egyes részleteket, szisztematikus megoldást választott. Egy glosszáriumban megmagyarázza, mit jelentettek az egyes alkímiai és fémműves terminusok a kortársak számára; ez a glosszárium önmagában izgalmas olvasmány az alkímia iránt érdeklődő olvasó számára. Külön függeléket szentel a 16. századi súly- és egyéb mértékegységek nehezen érthető rendszerének. Majd összeállítja azt az olvasmánylistát, amely Batthyány alkímiai tudását megalapozta, olyan könyvekből, amelyek bizonyíthatóan megvoltak a könyvtárában, és amelyekre levelezésében utal, és ezt a listát kiegészíti néhány, akkoriban mindenki által olvasott tétellel, amelynek ismeretét Batthyány sem tudhatta elkerülni. Végül a történeti szereplök is kapnak egy részletes ismertetést (őket egyébként a levelekhez füzött lábjegyzetek is azonosítják). A kötet gazdagon illusztrált, és részletes mutatók segítik a technikai részletek iránt érzékeny olvasót.

Bár a könyv soknyelvủ vállalkozás, az előszó, a jegyzetek és az említett függelékek angol nyelven készültek, és maguk a levelek is mind kaptak egy angol nyelvű glosszát (amely esetenként közel fele olyan hosszú, mint maga a levél). Így a könyv egyrészt a nem szaktörténész olvasók számára is jól követhető, másrészt 
pedig sokat fog segíteni abban, hogy a nyugat-európai történészek a hazai tudománytörténet e fontos fejezetére ne csupán mint egy egzotikus, de nehezen hozzáférhető perifériális epizódra tekintsenek, hanem első kézből tudják vizsgálni.

(Dóra Bobory editor: The Correspondence of Boldizsár Batthyány - The Everyday Life of an Early Modern Alchemist, Pécs: Kronosz Publishing House, 2019)

Láng Benedek

tudománytörténész Budapesti Műszaki és Gazdaságtudományi Egyetem Gazdaság- és Társadalomtudományi Kar Filozófia és Tudománytörténet Tanszék 